\title{
Influences of Cultural Differences between the Chinese and the Western on Translation
}

\author{
Guimei He \\ Qingdao University of Science and Technology, Qingdao, China \\ Email: hkmei@163.com
}

\begin{abstract}
The Factors of cultural differences on translation should not be underestimated .Exchange of different ethnic languages is essentially different cultural exchanges. We have to well master the two languages and deeply understand the two cultures, especially the differences between them. We'll overcome the barriers of language translation. This paper analysis the influences of the differences between the Chinese culture and the Western culture toward translation, from the perspective of religious belief, geographical environment, modes of thinking and different historical culture.
\end{abstract}

Index Terms - translation, ability of analysis, cultural difference, cultural factors

\section{INTRODUCTION}

We should make clear the definition of culture. We sometimes say that people who know about art, music, and literature are cultured. What do we mean by culture when we say different nations have different cultures? Obviously, culture in the sense is different from the concept of culture in the sense of excellent tastes in literature, music, philosophy, art, etc. The definition of "culture" as given in the Concise Oxford Dictionary varies from descriptions of the "Arts" to plant and bacteria cultivation and includes a wide range of intermediary aspects. More specifically concerned with language and translation. Culture is an extremely complex concept and an enormous subject. It embraces almost everything in the world, whether material or spiritual. The differences between English and Chinese culture bring more difficulties than the differences between linguistic structures. Language and culture have close relationship with each other. Translation is language translation and is even culture translation. Language, which possesses all the features of culture, belongs to institutional culture. Like all other aspects of culture, language is not inherited but acquired and shared by a whole society. Language mirrors other parts of culture, supports them, spreads them and helps to develop others. This special feature of language distinguishes it from all other facets of culture and makes it crucially important for the transfer of culture. It is no exaggeration to say that language is the life-blood of culture and that culture is the track along which language forms and develops. This comparative study of Chinese and English focuses on their differences, and we can conclude from it that differences in language arise from differences in mental culture. While translation is obviously a transfer of language, it is also a transfer of mental culture. Lotman's theory(1978) stated that: "no language can exist unless it is steeped in the context of culture; and no culture can exist which does not have at its center, the structure of natural language" (Lotman, 1978, p.211). Bassnett (1980) underlines the importance of this double consideration when translating by stating that language is "the heart within the body of culture,"(Bassnett, 1980, p.13) the survival of both aspects being interdependent. Linguistic notions of transferring meaning are seen as being only part of the translation process that a whole set of extra-linguistic criteria must also be considered.

\section{INFLUENCES OF CULTURAL DIFFERENCES TOWARD TRANSLATION}

\section{A. Religious Belief and Historian Historical Allusion}

Different religious beliefs exist in the Chinese and the Western cultures, It determines the differences of the two languages in many different ways of expression. The Westerners believe in Christianity. They think that God created everything.,while Buddhism and Taoism are the main religions in China. Many idioms related with religious beliefs appears in English and Chinese. Buddhism had more than 1000 years in China. So there are many religious vocabularies, such as “玉帝”、“观音”、“菩萨”、“佛主”、“慈悲为怀”. But in Western countries Christian Culture has the main position. The Bible is Christian Classics. In the formation and development of Western culture it has played an immeasurable role. Do not understand the Bible, it is impossible to understand Western culture and civilization. Religious beliefs permeate expressions of languages, and caused the different styles of the expression. In the Chinese Feudal society, people regard "heaven" as a domination of the nature, however, the Westerns regard "God" as the creator and the dominator and the God arranged all of things. “God helps those who help themselves”(上帝帮助自助之 人).

Example1: Liu laolao said that: “谋事在人，成事在天”。——“(《红楼梦》第六回) 
The translation of the sentence is: Man proposes, God disposes. Readers have to take liu laolao as a Christian. So Yang xianyi put it into English: Man proposes, Heaven disposes.

Example2: You are just a doubting Thomas. You won't believe what I tell you. The translation of this sentence is: 你 这个人真多疑，我说什么你都不信."doubting Thomas” comes from the Bible. Thomas is a student of Jesus who believed nobody. So Westerners regard it as “多疑之人”.

Example3: I believe, because of my religious faith, that I shall "return to Father in an afterlife is beyond description ."Here can we translate afterlife into “来世” or “来生”. If so, it seems not proper in this sentence. That is because“来世(lai shi) or“来生(lai sheng) all come from Buddhism term. In Christian countries, it can not be accepted by a Christian. In this sentence, the author's meaning is obvious, he or she refers to religious faith and Father. It is obviously that he or she is a Christian. Therefore it will be much proper if we translate afterlife into Chinese as: “人死 后的那段时光.”

As to religious culture, though we can find some words in Chinese equivalent to English words for the basic meaning, the words including the religious culture meaning which are quite different. For example, dragon and“龙”(long), the denotation of this two words are the same, but the connotation is totally different. In English, dragon stands for monster, demon or savage. But to Chinese, “龙”(long) is something sacred by most people, even it has been regarded as the ancestor of Chinese nation, that is why we Chinese people call ourselves“龙的传人”(descendants of the dragon), Chinese feudal emperors were often called“真龙天子”(zhen long tian zi), what they wear called “龙袍”（long pao）， where they were decorated with dragon. There are also many Chinese phrases related to “龙”, such as:“望子成龙(wang zi cheng long)”、“龙凤成祥(long feng cheng xiang)”. But to English speaking people, they can not accept such metaphor, in their mind dragon stands for evil or monster which can spit fire and possesses three to nine heads. For such consideration, there are very few English idioms with the word dragon, so“亚洲四小龙”was translated as “The four tigers of Asia."

When we translate the vivid story, we should know the cultural differences and the proper way to translate them. Chinese culture is abundant, so are other countries. There are also many allusions or proverbs, most of which are associated with the history and culture of a nation. Let us take "paint the lily" for example, if we do not know the culture which associates with it, we can not know the real meaning of this phrase or any hints from the phrases.

\section{B. Modes of Cognitive Thinking}

English national thinking is individual, unique, while the Chinese pay attention to collective. To the Chinese, thought is more important than form. What we care about is the conveyance of meaning; form is secondary. English-speakers place more emphasis on objective thinking, and focus on "what happened in any man" which is regarded as the product of scientific reasoning and analysis, while Chinese-speakers relatively pay attention to main body thinking, and place more emphasis on "what about the person" As a result, Chinese is a topic-dominated language while English is a subject-dominated language. A Chinese sentence revolves around a thought pivot, while English sentences rely on a form-pivot (or subject-predicate pivot). Therefore, the subject of a sentence is not as important in Chinese as it is in English. In Chinese, the subject is no more than the topic discussed; it can be a noun or a word of another class; any word that begins a sentence can be regarded as the subject because anything can be a topic. In English, the subject is the indispensable element of a sentence; it should be nominal and has a decisive grammatical function--even a slight change in the subject may affect the whole sentence. Hence, when translating from Chinese into English, it is very important to select a suitable subject for the establishment of the subject-predicate mechanism--the kernel of the translated sentence. Sometimes the subject should be amplified; other times it should be determined by the context, the logical relationship, or the need for concordance between subject and predicate. The translation of the following sentences give some examples.

Example1: 一边走着，似乎道旁有一个孩子抱着一堆灿白的东西。驴儿过去了，无意间回头一看，一看---他 抱着花儿，赤着脚儿，向着我微微的笑。冰心《笑》

"As I passed along, I somewhat sensed the presence of a child by the roadside carrying something snow white in his arms. After the donkey had gone by, I happened to look back and saw the child, who was barefoot, looking at me smilingly with a bunch of flowers in his arms". (Pr. Zhang Peiji, 1999) The Chinese thought pattern makes it possible to apprehend the subjects of 一边走着,(感到) 道旁有一个孩子, 无意中回头一看 immediately. In the English translation, « $\mathrm{I} »$ must be added three times in order for English readers to understand who is doing the action and for the sentences to be completed.

Example2: 不要有了新亲, 把旧亲忘个干净! 这种没良心的人我见得多了。钱钟书《围城》

“Once you have new relatives, don't forget the old ones. I've seen too many such ungrateful people”. (Dr. Jeanne Kelly \& Nathan K. Mao) The first sentence of the ST (source text) is subjectless. It is a piece of advice with an imperative function. Hence "You" (listener) is added. "I" is selected as the subject of the second sentence to make the version natural. The relationship between language and thought is dialectical and unified. On one hand, thought depends on language as material; On the other hand, thought dominates language.

Example3: “Nobody could be too foolish this day”. If this sentence is translated as“今天谁也不会太愚蚌”from the 
meaning of every word, it's really far away from the true meaning. In English, the meaning of this sentence shows the different mode of thinking. The right transition should be “今天无论怎么样出洋相, 都不过分”.

\section{Regional and Natural Environments}

Regional culture is formed by the natural condition, surrounding and location of districts. It manifests that different nations use different description on the same subject of phenomenon. Geographical features can be normally distinguished from other cultural terms in that they are usually value free, politically and commercially. Nevertheless, their diffusion depends on the importance of their country of region as well as their degree of specificity. (Newmark, 2001)

Different geographical environment affect weather and climate of different regions. And the climate also affects the use of language and the connotation of words.

For example, the regional cultures between Chinese and British are quite different. In China, it is known to all that south is in dominant place, people always say “从南到北”、“南来北往”、“南面为王北面为朝”、“南为尊北为卑”. But in English they are expressed in the other way, the English people often say "from north to south". In China, we say “西 北”、“西南”、“东北”、“东南”.But in English speaking countries, it is expressed like this: "north-west, south-west, north-east, south-east". East wind (东风), though the phrase refers to the same object, however, the connotation of the two words is not the same. In China, “东风”stands for spring, warm and agreeable weather. It can resuscitate the plants, so people have a deep feeling for it. In Britain, east wind symbolizes cold, unpleasant thing. Therefore western people loathe east wind, what they beloved is west wind. It comes along with spring. As we know, the romantic poet Sherry wrote a famous poem--Ode to the West Wind. At the end of this poem, he wrote like this: "o wind, if winter comes, can spring be far behind?" He wants to express his longing for future and firm belief. Another sentence is: "How many winter days have I seen him, standing blue-nosed in the snow and east wind"? When we translate it into Chinese, we have to consider the different regional culture, it should be translated like this, “在许多冬日里我总看见他, 鼻子冻得 发紫, 长在飞雪和西风之中”。If we translate “the east wind” into (东风之中), Chinese readers will misunderstand the real meaning of this sentence, because east wind in their mind are spring, warm and agreeable.

Because of geographical features of the English nations, their life is relevant to oceans whether in history or reality. Hence, there are lots of vocabulary about water in English. For example, in English, we use "spend money like water", but in China, we say“挥金如土”to express spending large sums of money. In England, there are many idioms about boats and water. And in China, there are not completely corresponding idioms, such as ,to rest on one's oars(暂时歇一 歇), to keep one's head above water(奋力图强),all at sea(不知所措)。Geographical and environmental elements are also part of one's nation's culture.

\section{CONCLUSION}

Chinese and English--the two languages derive from different cultures and carry different culture. This will inevitably result in some differences in the expression of the two languages. Different language may use different linguistic forms, but these forms are only one of the aspects of the difference between the two language systems. To handle the cultural differences on translation, one has to understand deeply a foreign nation's culture and language and learn to master how to use c-e translation in the cultural exchanges

If the reality being represented is not familiar with the audience, the translation stumbles and becomes different to read. The translator would have to consider whether similar or parable language resources exist in the literary subculture of the target language. So the translator should possess two cultural apprehension and the ability to use the language, and we must constantly improve our cultural accomplishment. We should overcome the barrier of both Chinese and Western culture, and respect other peoples' cultures, respect one's own nation's culture as well so as to achieve the purpose of the cultural communication.

\section{REFERENCES}

[1] Jury Lotman. (1978). On the Semiotic Mechanism of Culture. New Work History, p.211.

[2] Bassette, Susan. (1980). Translation Studies. London: Between \& Co. Lid.p.13-23.

[3] Peter Network. (2001). A Textbook of Translation, Shanghai Foreign Education Press. p.217.

[4] Engage A. Nidi. (2001). language cultural and translating, Shanghai Foreign Language Education Press.

[5] Zhang Peiji, (1999). Chinese Modern Prose. Shanghai Foreign Language Education Press.

[6] Dong Yanchang, Liurunqing. (1989). Language and Culture. Beijing: Foreign Language Teaching and Research Press.

Guimei He was born in Qingdao, China in 1957. She majored in English Linguistics and Literature in the Department of Foreign Studies, Liaocheng University, China in1978-1982.

She is currently an associate professor at College of Foreign Languages, Qingdao University of Science and Technology. Her interests include international communication and foreign language teaching. 